\title{
A Study of Local Wisdom of Balinese Aga And Samin People to Develop Environmental Awareness Characteristics
}

\author{
Sumarmi \\ Faculty of Geography, \\ Universitas Negeri Malang, \\ Malang, Indonesia. \\ Corresponding Email: sumarmi.fis@um.ac.id
}

\begin{abstract}
To overcome as well as to lessen the number of environmental problems in Indonesia, people within this country need to have high awareness and concern in conserving the nature and environment. One of the national educational goals in Indonesia is to bring out intelligent and well-mannered generations, and one of the goals in learning Geography is to build up environmental awareness characteristic. Local cultural wisdom has been living and spreading in every part of Indonesia archipelago. It has also been integrated and put up in people's living routines and practices. This study revealed that the local cultural wisdom of Balinese Aga and Samin people is highly related to environmental conservation and continuity. Therefore, positive values and attitudes are prominently needed to build and to improve the characteristics of environmental awareness, which should be introduced and familiarized to students starting from young age through formal education, trainings, and convention.
\end{abstract}

Keywords-Local wisdom, environmental awareness characteristic

\section{INTRODUCTION}

This study basically grounds on the environmental problems currently happening in Indonesia, which unfortunately are getting more complicated from time to time. Natural disasters have been coming to people's environment, such as flood, landslide, drought, forest fire, expansion of critical lands, lowered amount of clean water, and many others.

To overcome such problems, Indonesians need to have awareness and concern in conserving their environment and nature. Indonesia has been well-known for its vast areas with all natural resources and varied customs spreading in many zones of land. Each has particular local wisdom to manage the environment. Such a local wisdom is generally regarded to be local conceptions which are advisable, prudent, useful, and appropriate to apply and put up in local people's life and practices (Sartini, 2004). By the existence of local people's prudence and wisdom, environmental condition will stay in accordance with the right order of environmental system. Besides, the local wisdom that people have been widely applied in their society has been integrated with local systems of belief, norms, and cultures, and also actualized in local traditions and myths and then held in the highest regards for a very long time.

The local wisdom is not mere traditional values or typical traits of localities. It is further associated with traditional values carrying uses and benefits to attain and maintain people's living needs, including to maintain the quality and quantity of natural resources in Indonesia. Diverse intents of maintaining the environment result in various uses of local wisdom as well. The uses, hence, cover some notions including: (1) the local wisdom functions as a key to conserve natural resources; (2) the local wisdom works on developing or improving human resources; (3) it serves some strategies to improve cultural values and knowledge; (4) it stands as admonition, belief, literature and also prohibition.

One of the educational goals in Indonesia is basically to bring out intelligent and well-characterized generations. People having appropriate characters, in this case, are those who are highly responsible for conserving and maintaining the natural resources and environment through their local cultural wisdom. Additionally, Geography learning is expected to make happen and finally to improve positive traits like honest, responsible, concern, aware, and environmental-friendly. This is generally to provide effective support and solution to overcome the problems in social and natural environments.

\section{METHOD}

This research employs descriptive qualitative method. The data were taken from literature reviews and also field observation which was held in: (1) Balinese Aga in Tenganan Village, Manggris Sub-district, Karangasem District, Bali; and (2) Samin People in Klopodhuwur Subdistrict, Banjarejo District, Blora District, Central Java. People living in those areas have been applying local wisdom to manage and conserve their living environment. For such reasons, Balinese Aga and Samin people are regarded to be the appropriate subjects under study. The 
data were collected through in-depth interview and observation in the fields.

\section{FINDINGS AND DISCUSSION}

\section{A. The Local Wisdom of Balinese Aga in Tenganan Village, Manggris Sub-district, Karangasem District, Bali}

Tenganan Village is situated in a very accessible and strategic area. Typographically, the village is halfsurrounded by hills on the north side and is bordered with some villages adjacent to sea on the south side. The presence of Tenganan Village is actually shaped from its people and their behavior and treatment towards the nature, environment, and tradition around them. The tradition that has been living there since the old times, furthermore, leads the Tenganan village to be a well-known and fabulous cultural tourism.

The custom and tradition commonly applied by Balinese Aga in Tenganan Village hold a particular sense signifying the balance between people's living practice and endeavor and their nature. People's daily activities are supposed to harmoniously orient to the nature in order to pursue contentment and satisfaction when fulfilling their living needs. Besides, harmonious relations between people and God, people and their fellowship, and also people and their nature, are the other matter to hold for the reason of achieving life contentment.

Tenganan people carry out the meaning of Galungan and Kuningan based on Tri Hita Karana belief. The celebration of those holidays has been practically implemented in people's daily life. The ideology underlining triumph of dharma against adharma is represented through good deeds and courteousness in managing harmonious relations between people and their God, their society, and also their environment. Offerings, worship, devotion, moral comportment, and proper conduct in daily life are some forms of people's faithfulness and loyalty to their God. Such decent manners are basically taken from the knowledge, experience, and good learning in overall people's life journey. For example, people there mostly keep a close and intimate family relation by strongly prohibiting a marriage with outsiders or with people coming from other villages. People's relation to the outsiders are restricted and confined by the so-called awig-awig, which is all then regarded to be a representation of wisdom and prudence there.

Tenganan people's relation to their nature is defined more by the symbol of awig-awig and local belief related to that than by the government's policy and regulation. In other words, local policy and regulation there work more commendably than the rules made by officials. For instance, people cannot cut down any trees, neither the trees of personal ownership in their own house lands nor the trees on the outside house lands. Otherwise, people will have to pay two-time fines from the trees' former price and about 40-75 thousand rupiahs (depending on the violation) to the local office. What is more, people can be discharged from their official job or position and then exiled from society because, as officials, they are assumed to be improper model that cannot firmly hold onto regulation.

Woods on the half-rounded hills are often pertained to be related to sacred places. The forests are assumed to be the house of Gods, which make people there commonly pray and do sacred practices. Besides, people build the forests into some sorts of temples where they do the prayers and rituals. Through such acts, subtly, people believe that they have been preserving the forests, including Kaje, Kangin, and Kauh Hills.

Another matter to spot is that the making of fabric which mostly makes use of the nature. It becomes one of the main reasons that people there have to conserve and maintain the tress and plantation. This concept has been growing and implementing by Tenganan people, and also seen as a mutually beneficial relationship between people and their nature. The nature provides people with most of people's living needs, and consequently people have to conserve the nature in the best attempt they can get done.

The tradition of perang pandan or megeret pandan comes from the belief of Sekta Indra, meaning the balance of bhur, bwah, and swah (tri angga). During the celebration of such a tradition, there are dances presented to God (bhur) and held for making betterment of human's relationship (bwah), and there are also dripping blood tradition offered to Butha Kala (swah). Overall, the dances are intended to achieve the balance of nature. Another tradition based on Sekta Indra is meresi rituals which the dances use daggers (keris).

Ngayah custom in Tenganan Village has become people's daily routines. It is not necessarily defined by a certain program as it turns out to be a routine in daily life, instead. For example, people there have been doing ngayah activity involving environment cleaning every-single-day. Meanwhile, people in other parts of Bali just put it on a monthly program. Besides, waste disposal management in Tenganan Village has already been in appropriate control and system even before the socialization of modern system of waste disposal management. Inopportunely, people there are still challenged by some constraints for recycling the waste to be economical, useful and even commercial products. Organic waste is basically biodegradable, and it is possible to be made into organic fertilizer. On the other hand, plastic or non-biodegradable waste is put in to the village dump. Despite the fact that government still has not provided any helps to Tenganan people, their management of waste disposal is good already, indicated by their garbage-free environment. The division of lands has been clear and structured since a long time ago, causing the people living finally to see and aware of which part of lands they are responsible to clean and conserve. For example, if a family owns a part of house yard or some parts of lands, it is their own responsibility and task to clean, manage and conserve the lands and environment. They cannot pass the 
task on to other people since other people might have the same responsibility to keep their lands and environment clean and balanced. In addition to that, the division of lands is based on how long people have been living and spending their life in the village. Married people are responsible for Bale Agung, while terune or young people or those who are not married yet stay in Bale Petemu. Such divisions including the Bales are considered sacred and very wellregarded by the people there.

The ultimate purpose of Tenganan people for conserving their environment is that because they do not want others take what they currently own. Such a belief motivates them a lot as they attempt many possible things to preserve their lands especially from capitalists. People there are not easily tempted by how much money they will get from selling the lands. They precisely assign a priority for devolving the lands, environments, and all natural resources in it to their generations. By continually doing such a tradition, they, accordingly, can be able to preserve and maintain both nature and tradition, especially the customs that have been there since the past era.

Pasut people also conduct Ngayah as a form of environmental cleaning activity in some coast areas. However, they have a special ritual done prior to cleaning the environment, which is to do a prayer to ask for Sang Hyang Baruna's (representation of God as the 'controller' of sea) blessings. Though the activity and ritual are monthly held, people there commonly intensify the rituals on holidays, like Galungan, Kuningan, Pagerwesi, Siwalatri, Nyepi, and Rahina including Purnama and Tilem. People living there also have high awareness to preserve their environment, especially the areas around coast in Pasut. Pasut people keep up on doing the cleaning activity certainly to maintain the clearness and purity of beach. They are also aware that the quality of environment, including coast areas, really depends on how people living there behave and maintain the up land areas.

\section{B. Local Wisdom of Samin People in Blora, Central Java}

Samin people mostly live in Blora. One of the traditional ceremonies commonly held there is nyadran (a ritual to 'clean' the village from any possible misfortune), and also a ritual to drain the springs which supply people's needs the most. People there also have a sort of local assembly, usually called sarasean and held on every Kliwon days of Tuesday and Friday, in order to uphold the values of togetherness and deliberation and also to provide knowledge and learning to people especially the young generations. By that, people can learn how to live in society, to treat society in the right and well deeds, to uphold social harmony, to sustain Javanese local culture, and finally not to mind too much distinction for one to another as people are essentially the same before Him.

Samin people view their environment and nature very positively. They make use of the nature efficiently, for example, by getting the woods from the forest only as much as they need. Importantly, they never intend to exploit the nature. To them, lands are their mother of earth, meaning that the lands are the ones giving them life supplies and supporting their living needs. People there also consider lands and all natural things around them similar to their fellowship and family who need one to another to sustain the lives. Some of them even do not eat fish or meat for they want to show consideration for the nature. The common tradition and belief that people do once they want to make use of the nature is that to always ask for permission to the 'owner' of the lands, or nembung in Javanese term. More to say, they regard all things in the nature to be under the ownership and custody of the 'owner' of earth, which, as a result, makes them always careful and proper when asking for permission before using the natural resources. A lot of positive values in Samin people's life are worth learning. One of them is to get accustomed to the values of cooperation and mutual assistance. People there also emphasize on a saying mentioning that "never correct others' flaw before being able to rectify our own mistakes"

Characteristics are a set of values directed by certain systems and intended to control people's thought, behavior, and attitudes (Anwar, 2008). Characteristics are often linked to personalities. Personalities cover particular forms of traits, characteristics, styles, and special attributes of people, which are originated or shaped from society and social interactions. Characteristics contribute importance in people's life. For example, it is the characteristic that drove Japanese to stand after their failure in World War II and they were finally able to restore their honorable name before all nations in the international world. It is also due to the characteristic that makes Vietnamese hard to defeat. Vietnam even has taken over two superpower countries in technology and economics, such as France and USA. The result of character building has, moreover, impacted South Korea to be a more advanced country in many fields. It even has overpowered Indonesia, despite the fact that both Indonesia and South Korea were once in similar state of economic and technological development. Taken such cases as a whole, it is vivid that it is the character building that initiates the veterans who combatted colonialism to bring Indonesia into the whole independence (Raka, 1997).

Values and description of Cultural Education and National Character Building cover several aspects of traits, such as religiousness, honesty, tolerance, discipline, hardworking, creativity, independence, inquisition, nationalism, patriotism, appreciation, merit, communicative and friendly relation, peace, having reading habit, having strong awareness to nature, environment, and social life, and also responsibility.

Character building is achievable through some attempts, like formal education, trainings, consultation, and practices of accustoming the characteristics to people's life. In primordial society, character building program should cover the best attempts and policies that help students or undergraduate students to critically see the reality. In fact, 
environmental condition in Indonesia is currently dropping more and more, and even some areas are getting more critical. Still, there are some places which condition is preserved and maintained well. People's character building, in this case, is regarded to be one of effective attempts to conserve the environment and also to restore the condition of critical lands. Besides, character building program is prominently beneficial to overcome current global problems and even the greater problems that possibly happen in the future.

Most Indonesian ethnical groups or tribes own particular perception, knowledge and wisdom in using and maintaining all natural resources in their environment. Culture is basically a part of local knowledge and tradition, which then becomes the basis of people's viewpoints especially in the points of managing the activities related to nature and environment. Norms and values contained in the insight of culture and civilization are well known as local wisdom. Such a local wisdom constitutes some forms of responses based on humans' interaction to their nature. It also becomes a key of environmental ethics which are applicable in social life. In overall description, the local wisdom is a real part environmental ethic implementation (Marfai, 2012).

The local wisdom belongs to one of geographical phenomena in humans' life, shown by the mutual interaction between humans and their nature. It, conceptually, turns out to be the element of culture, and, specifically, takes a certain portion in traditional knowledge system. Furthermore, the key point of local wisdom, substantively, is justifiable through several aspects, such as local concepts, folklores, religious rituals, local beliefs, prohibitions and advice. Practically, the local wisdom is seen as a set of traditional systems involving three basic dimensions; the dimension of cultural potency, the dimension of methods and approaches emphasizing on wisdom and prudence, and the dimension of aims and directions underlining harmonious, balanced, and continuous life (Geriya, 2004).

In the current globalization era, technology and science have been going through massive development, resulting on some alteration in the environment. However, the advancement of technology is doubted due to some assumptions mentioning that technology can precisely damage the natural environment and even brings further probable disasters. Considering such a belief and condition, people need to contemplate on how they should behave, manage and retain the wisdom in order to preserve the natural environment around their living places (Herawati, 2004).

In the past, our ancestors had specific local wisdom in conserving their natural environment, and interestingly each place had different strategies and wisdom for achieving the goals of such conservation attempts. For that case, people now are supposed to be responsible to explore and maintain the local wisdom, and finally expand it to the younger generations, like students or undergraduate or graduate students, through some activities involving outright learning or materials compiled by teachers or lecturers. Those all are certainly for building the characteristics to conserve the nature and environment.

Indonesia is considered wealthy for having a variety of cultures. Taking it into account, the local wisdom in Indonesia which is linked to the use of nature needs to be explored more intensively. Specifically, the exploration is supposed to cover some areas, like; (1) Papua, where people lay their belief in the concept of te aro neweak lako (nature is me). Ertsbeg and Grasberg mountains are believed to be head of mothers, and lands are considered the main element of humans' life. By that, people should make use of the nature and environment very carefully and wisely; (2) Serawai, Bengkulu. People there believe in celako kumali. Environmental conservation is achievable for people who have strong belief on the values of taboo especially in the tradition of cultivating lands and tanam tanjak; (3) Dayak Kenyah, East Kalimantan, where there is tana'ulen tradition. Forests belong to local people, and, thus, the conservation is controlled by the local regulation; (4) Undau Mau society, West Kalimantan. People there maintain the local wisdom to manage the arrangement of living place or residences by classifying the forests and then making use of them. Land cultivation uses rotational system on bera period. Besides, the people believe in the ideas of taboo, especially when cultivating their lands, so that the use of technology is limited only on simple and environmentalfriendly tools; (5) Kasepuhan Pancer Pangawinan society, Kampung Dukuh, West Java. People there understand the customs of traditional ceremonies, myths, and taboos. As a result, they always make use of the forests very carefully. People are also prohibited to exploit the lands, unless the elders permit them to do so; (6) Bali and Lombok, where people have awig-awig. Diemas Dhamardjati.

Some local wisdom that is currently guiding people involves some traditions in some places, such as in Jawa (Pranoto Mongso, Nyabuk Gunung, turning some areas into sacred places), Sulawesi (prohibition, offers, and sactions), and Badui Dalam (buyut, pikukuh, and dasa sila), subak tradition in Bali which comes in form of water distribution for irrigating the crops, sasi in Maluku and Papua that is to prevent the excessive fish catching, zoning in Papua and karuhun in Sunda that is to manage lands, forests and water in the local areas, and also leuweung in Sunda that is to manage the areas and make use of forest and lands. Those are some samples of the local wisdom that implements environmentally-friendly strategies and brings positive impacts to people's daily life.

The relationship of Balinese Aga and their environment, in Tenganan, Bali, is strongly bonded by the awig-awig and their local belief. They put more consideration on those matters than on government's law and regulation. For example, people are prohibited to cut down any trees, even if the trees personally belong to people there. If people 
violate such a rule, they will get sanctioned as they have to pay two-time fines from the actual price of the trees. Moreover, people with position or job in the local areas will be discharged from their position and even exiled from society. The highest penalty is called kutang banjar/kesah.

Aulia (2010) documented that the local wisdom in Kampung Suta, West Java, includes the culture of pamali when conserving water. The regulations involve: (1) prohibition to go into the sacred forest, except on Friday and Monday, (2) prohibition to spit out and throw out in the area of sacred forest, (3) prohibition to seize and kill any animals in the sacred forest, (4) prohibition to break any branches and even to cut down the trees in the sacred forest, and (5) prohibition to go into the sacred forest without being accompanied by the forest keeper or kuncen. The local cultural wisdom of pamali result positively on the attempts of conserving the nature and resources in Kampung Kuta.

This study specifically underlines the ideas of implementing the whole characteristics of environmental awareness by: (1) involving students to find broad information about the topic/theme related to local wisdom; (2) employing various learning approaches, learning media, and learning sources (using examples of local wisdom values, which is going to be familiarized to students in all grades so that they can be more responsible and aware to conserve the local wisdom in their living places; (3) facilitating students who conduct observation directly on the fields by showing them the examples of good and conserved local cultural wisdom in some areas; (4) assigning students to explore more information, either written or interview with relevant and valid sources, in order to evoke new ideas and strategies to conserve the nature and environment and to recover some problematic areas; (5) facilitating students to make exploration report noting about the condition of environment, either individually or in groups; (6) facilitating students to present the result of their work, so the student can well-realize the characteristics, traits, and pride to conserve nature.

\section{CONCLUSION AND SUGGESTION}

To wrap up the above findings and discussion, this study infers that the local cultural wisdom has been living in most Indonesians' living places, and even has been running in a certain place for a very long time. It is generally linked to the strategy and characteristics of nature's conservation and environment's continuity. Therefore, the implementation of local cultural wisdom, which has been applied for a long time by Balinese Aga and Samin people, effectively works for building the students' characteristics to conserve the nature. The local wisdom learning can be put into some of the educational systems involving formal education, trainings, convention and customary practices.

Considering the main points of discussion and conclusion in previous sections, this study takes a result that:
1. Improving the characteristics of environmentallyaware stands in very high prominence in social life, which is all intended to assure the betterment and continuity of nature conservation in Indonesia.

The local cultural wisdom has been working on many ethnical groups in Indonesia. Accordingly, character building program is really worth applying, and teachers at schools are supposed to master the local cultures prior to teaching them to the students. Importantly, contextual teaching and learning strategies are essential to support such a program.

\section{REFERENCES}

[1] Anwar, Qomari, 2008, “Agama Nilai UtamaDalam Membangun Karakter Bangsa”( www.kopertis3.or.id/.../bidakara-sarasehan)

[2] Aulia, TOS, dkk, 2010, "Kearifan Lokal Dalam Pengelolaan Sumberdaya Air Di Kampung Kuta Local Wisdom of Water Resource Management in Kampung Kuta”, ISSN : 1978-4333, Vol. 04, No. 03 5Sodality: Jurnal Transdisiplin Sosiologi, Komunikasi, dan Ekologi Manusia | Desember 2010, hlm. 345-355. Bogor: Departemen Sains Komunikasi dan Pengembangan Masyarakat, Fakultas Ekologi Manusia, IPB.

[3] Geriya, I Wayan, 2004, "Nilai Dasar, NilaiInstrumental dan Referensi Hukum dalam Kearifan Lokal Daerah Bali”,Majalah Kerta Wicaksana,Denpasar, Fakultas Hukum Universitas Udayana.

[4] Herawati, Isni,2004,'Kearifan Lokal diLingkungan Masyarakat Using Kabupaten Banyuwangi Propinsi Jawa Timur”,Yogyakarta. Balai Kajian Sejarah dan Nilai Tradisional Yogyakarta.

[5] Marfai Muh Aris,2012,"Pengantar Etika Lingkungan dan Kerifan Lokal", Yogyakarta. Gadjah Mada University Press.

[6] Raka, I Dewa Gede, 2008,"Pembangunan karakter dan pembangunan bangsa:Menengok kembali peran perguruan tinggiDisampaikan pada Sidang Terbuka Majelis Guru Besar Institut Teknologi Bandung di Balai Pertemuan Ilmiah ITB”, 28 November 2008.

[7] Sartini. 2004. Menggali Kearifan Lokal Nusantara Sebuah Kajian Filsafat. Jurnal Filsafat, Agustus 2004, Jilid 37, Nomor 2. 